\title{
MODEL PREDIKSI TINGKAT KESEHATAN BANK MELALUI RASIO CAMELS
}

\begin{abstract}
Early from monetary crisis is which knock over Indonesia of around year 1997 - 2008 causing private sector and also "persero" banking finding difficulties finance, even happened the liquidation bank and freezed. Pursuant to the background, hence problems which wish lifted in this research is whether CAMELS ratio consisted by the CAR, KAP, $A P B, N P M, R O A, R O E, B O P O, L D R$, and IRR have the influence in prediction mount the health of banking in period 2004-2008?

Population in this research is which banking go public with amount of sampel equal to 80 sampel of financial statement banking from 16 bank during period 2004-2008. The statistic methods which is used to test on the research hypothesis is logit regression. The result show that the financial ratio to influence the determination health of bank are ROA and IRR with the storey level significant of equal to 0,003 and 0,018. The mentioned in line with research conducted by Titik Aryani \& Hekinus Manao (2002)
\end{abstract}

Key words : Health of Bank, Ratio CAMELS, Logit Regression.

\section{PENDAHULUAN}

Berawal dari adanya krisis moneter secara global yang menghantam kawasan asia khususnya di Indonesia, secara langsung telah menghantam perekonomian di seluruh kawasan tersebut. Pertengahan tahun 1997 perbankan baik swasta maupun persero banyak mengalami kesulitan keuangan, sehingga pada 1 November 199716 bank dilikuidasi, 7 bank dibekukan operasinya pada April 1998, dan pada 13 Maret 1999 terdapat 38 bank yang dilikuidasi (Info Bank no. 326, Mei 2006).

Berawal dari terjadinya likuidasi terhadap beberapa bank membuat sektor perbankan banyak disorot. Apalagi dengan ada indikasi meningkatnya non performing loan dan terjadinya negative spread, menyebabkan krisis perbankan mencapai puncaknya. Tidak ada lagi penyaluran kredit membuat lembaga ini kehilangan fungsinya sebagai perantara antara kegiatan tabungan dan investasi. Bukan saja bank itu sendiri yang merugi, tetapi juga sangat mengganggu jalannya roda perekonomian.

Langkah mendesak perlu dilakukan untuk mengatasi krisis moneter yang terjadi pada saat itu yaitu dengan mengadakan penyehatan perbankan. Tanpa upaya tersebut berbagai kegiatan sektor riil, dari kebutuhan investasi sampai dengan transaksi perdagangan akan tersendat. Untuk mencegah terulangnya kembali krisis moneter melanda Indonesia yaitu dengan cara perbankan di Indonesia harus sehat dan baik. Sehat dan tidaknya suatu bank dapat dilihat dari laporan keuangan yang dibuat oleh pihak bank itu sendiri dengan cara dilakukan analisis terhadap laporan keuangan tersebut.

Dari uraian di atas maka penulis tertarik untuk melakukan penelitian pada perusahan perbankan yang go 
publik di Indonesia dengan pengambil judul "Analisis Kinerja Keuangan dengan Rasio CAMELS (Capital, Asset Quality, Management, Earning, Liquidity, Sensitivity to Market Risk) untuk Memprediksi Kesehatan Perbankan (Studi Kasus pada Perbankan Go Publik)". Analisis kesehatan perbankan dengan menggunakan rasio CAMELS diatur dalam Peraturan Bank Indonesia No. 6/10/PBI/2004 tertanggal 12 April 2004 dan SE BI No. 6/23/DPNP tgl 31 Mei 2004 tentang Sistem Penilaian Tingkat Kesehatan Bank Umum mencakup penilaian terhadap faktor - fakor CAMELS (Capital, Asset Quality, Management, Earning, Liquidity, Sensitivity to Market Risk).

Berdasarkan uraian di atas, maka permasalahan yang ingin diangkat dalam penelitian ini adalah : Apakah rasio CAMELS yang terdiri dari CAR, KAP, APB, NPM, ROA, ROE, NIM, BOPO, LDR, dan IRR mempunyai pengaruh yang signifikan dalam memprediksi tingkat kesehatan bank periode 2004-2008. Sedangkan tujuan yang ingin dicapai dalam penelitian ini adalah untuk memperoleh bukti empiris apakah rasio CAMELS yang terdiri dari CAR, KAP, APB, NPM, ROA, ROE, BOPO, LDR, dan IRR mempunyai pengaruh dalam memprediksi tingkat kesehatan bank periode 2004-2008. Diharapkan penelitian ini bermanfaat bagi kalangan akademik maupun perusahaan perbankan dalam rangka memprediksi tingkat kesehatan perbankan dengan menggunakan rasio CAMELS.

\section{TELAAH LITERATUR DAN PENGEMBANGAN HIPOTESIS}

\section{Aspek Permodalan}

Aspek permodalan dalam penelitian ini berdasarkan pada komponen kecukupan pemenuhan KPMM terhadap ketentuan yang berlaku. Dalam penelitian ini aspek permodalan diwakili oleh komponen CAR. Menurut Tarmizi Ahmad \& Wilyanto Kartiko Kusuno (2003:62) menerangkan Capital Adequacy Ratio (CAR) merupakan rasio permodalan yang menunjukan kemampuan bank dalam menyediakan dana untuk keperluan pengembangan usaha dan menampung kemungkinan resiko kerugian yang diakibatkan dalam opersional bank. Bank yang dianggap sehat adalah bank yang memiliki Capital Adequacy Ratio (CAR) di atas 8\%, sehingga semakin tinggi CAR mengindikasikan semakin baik tingkat kesehatan bank. Maka dapat dikembangkan hipotesis (H1) : Rasio Capital Adequacy Ratio (CAR) mempunyai pengaruh dalam memprediksi tingkat kesehatan bank.

\section{Aspek Kualitas Asset}

Aspek kualitas asset dalam penelitian ini diwakili oleh KAP \& APB. Rasio KAP itu sendiri digunakan untuk mengetahui kemampuan bank dalam menjaga dan mengembalikan dana yang digunakan dan mengukur tingkat kemungkinan diterimanya kembali dana yang ditanamkan. Semakin tinggi rasio KAP memperlihatkan kondisi kesehatan bank semakin buruk.. Sedangkan APB menunjukan kemampuan management bank dalam mengelola aktiva produktif bermasalah terhadap total aktiva produktif. Semakin tinggi rasio ini maka semakin buruk kualitas aktiva produksi yang menyebabkan Penyisishan Penghapusan Aktiva Produktif (PPAP) yang tersedia semakin besar, maka kemungkinan suatu bank dalam kondisi bermasalah atau tidak sehat semakin besar. 


\section{Aspek Manajemen}

Aspek manajemen pada penelitian analisis kesehatan perbankan tidak dapat menggunakan pola yang ditetapkan Bank Indonesia, tetapi diproksikan dengan profit margin (Merkusiwati, 2007) dalam Enik Sulastri (2009). Alasannya, seluruh kegiatan manajemen suatu bank yang mencakup manajemen permodalan, manajemen kualitas aktiva, manajemen umum, manajemen rentabilitas, dan manajemen likuiditas pada akhirnya akan mempengaruhi dan bermuara pada perolehan laba. Semakin besar rasio NPM mengindikasikan tingkat kesehatan bank semakin bagus. Maka dapat dikembangkan hipotesis (H4) : RasioNetProfitMargin (NPM) mempunyai pengaruh dalam memprediksi tingkat kesehatan bank.

\section{Aspek Rentabilitas}

Tingkat rentabilitas yang sehat merupakan salah satu tujuan setiap bank karena rentabilitas digunakan sebagai alat untuk mengukur seberapa besar kemampuan manajemen dalam menghasilkan laba atas asetaset yang ditanamkan dalam perusahaan tersebut dan juga menunjukan kemampuan manajemen dalam menekan biaya operasionalnya. Dalam penelitian ini tingkat rentabilitas secara kuantitatif dapat dinilai dengan beberapa indikator antara lain dengan rasio ROA, ROE, NIM, BOPO.

Return On Asset (ROA) digunakan untuk mengukur kemampuan manajemen bank dalam memperoleh keuntungan (laba sebelum pajak) yang dihasilkan dari rata-rata total asset bank yang bersangkutan. Semakin besar ROA semakin besar pula tingkat keuntungan yang dicapai bank sehingga kemungkinan suatu bank dalam kondisi tidak sehat semakin kecil. Maka dapat dikembangkan hipotesis (H5) : Return on Asset (ROA) mempunyai pengaruh dalam memprediksi tingkat kesehatan bank.

Return On Equity (ROE) digunakan untuk mengukur kinerja manajemen bank dalam mengelola modal yang tersedia untuk menghasilkan laba setelah pajak. Semakin besar ROE semakin besar pula tingkat keuntungan bank yang dicapai bank, sehingga kemungkinan suatu bank dalam kondisi tidak sehat semakin kecil. Maka dapat dikembangkan hipotesis (H6) : Return on Equity (ROE) mempunyai pengaruh dalam memprediksi tingkat kesehatan bank.

Net Interest Margin (NIM) digunakan untuk mengukur kemampuan manajemen bank dalam mengelola aktiva produktifnya untuk menghasilkan pendapatan bunga bersih. Pendapatan bunga bersih diperoleh dari pendapatan bunga dikurangi beban bunga. Semakin besar rasio ini maka meningkatnya pendapatan bunga atas aktiva produktif yang dikelola bank, sehingga kemungkinan suatu bank dalam kondisi bermasalah atau tidak sehat semakin kecil. Maka dapat dikembangkan hipotesis (H7) : Net Interest Magin (NIM) mempunyai pengaruh dalam memprediksi tingkat kesehatan bank.

Rasio Beban Operasional terhadap Pendapatan Operasional (BOPO) digunakan untuk mengukur kemampuan manajemen bank dalam mengendalikan biaya operasional terhadap pendapatan opersaional. Bank yang dalam usahanya tidak efisien akan mengakibatkan ketidak mampuan bersaing dalam mengerahkan dana masyarakat maupun dalam menyalurkan dana tersebut kepada masyarakat yang membutuhkan sebagai modal usaha. Dengan adanya efisiensi pada lembaga perbankan terutama efisiensi biaya maka akan diperoleh 
tingkat keuntungan yang optimal, peningkatan pelayanan kepada anasabah, keamaanan dan kondisi kesehatan bank semakin meningkat. Semakin besar rasio BOPO mengindikasikan pendapatan operasional yang diperoleh tidak dapat mengcover beban operasional yang dikeluarkan sehingga kemungkinan bank mengalami kondisi tidak sehat semakin besar. Maka dapat dikembangkan hipotesis (H8) : Beban Operasional terhadap Pendapatan Operasional (BOPO) mempunyai pengaruh dalam memprediksi tingkat kesehatan bank.

\section{Aspek Likuiditas}

Kemampuan bank untuk dapat membayar semua kewajiban jangka pendek pada saat jatuh tempo merupakan salah satu faktor menentukan kondisi suatu bank. Apabila mampu melakukan pembayaran artinya bank dalam keadaan likuid, tetapi jika bank tidak mampu melakukan pembayaran, maka bank dikatakan tidak likuid. Dalam penelitian ini aspek likuiditas diwakili oleh komponen LDR.

Loan to Deposit Ratio (LDR) merupakan indikator kemampuan bank untuk mengimbangi kewajiban untuk segera memenuhi permintaan deposan yang ingin menarik kembali uangnya yang telah digunakan oleh bank untuk memberikan kredit. Apabila dari banyak keredit yang diberikan tidak diimbangi dengan jumlah dana yang terkumpul menyebabkan likuiditas dari bank berkurang. Maka rasio LDR tersebut harus berada di batas aman, apabila berada di luar batas aman akan menyebabkan likuiditas bank terganggu yang pada akhirnya akan berpengaruh pada keputusan untuk melikuidasi bank tersebut. Maka dapat dikembangkan hipotesis (H9) : Loan to Deposit Ratio (LDR) mempunyai pengaruh dalam memprediksi tingkat kesehatan bank.

\section{Aspek Sensitivitas}

Dalam penelitian ini faktor sensitivitas terhadap resiko pasar diproksikan dengan resiko suku bunga yang merupakan variabel yang paling dominan dalam menilai resiko pasar. Resiko bunga merupakan potensi timbulnya kerugian akibat bergeraknya suku bunga pasar kearah yang berlawanan dengan portofolio pasar. Resiko suku bunga dalam penelitian ini dilihat melalui rasio IRR, dimana Interst Risk Ratio (IRR) itu sendiri merupakan rasio yang digunakan untuk mengukur kemungkinan bunga yang diterima oleh bank lebih kecil dibandingkan dengan bunga yang dibayarkan oleh bank.

Pengaruh perubahan tingkat bunga terhadap pendapat bunga bersih pada bank secara umum tergantung pada pendapatan bunga dan beban bunga. Semakin besar rasio ini maka menunjukan arah yang positif dalam menghadapi resiko pasar sehingga kemungkinan bank mengalami kondisi tidak sehat semakin kecil. Maka dapat dikembangkan hipotesis (H10) : Interest Risk Ratio (IRR) mempunyai pengaruh dalam memprediksi tingkat kesehatan bank.

\section{METODE PENELITIAN}

\section{Populasi dan Sampel}

Populasi dalam penelitian ini adalah perusahaan perbankan yang go publik di Indonesia antara tahun 2004 s/d 2008. Pengambilan sampel dengan menggunakan metode purposive sampling yang didasarkan pada 
beberapa kreteria, yaitu : tersedia data laporan keuangan dari tahun 2004 s/d 2008, Merupakan bank publik (bukan bank asing) yang listing di Bursa Efek Indonesia sampai dengan tahun 2008

\section{HASIL DAN PEMBAHASAN}

\section{Data Penelitian}

Berdasarkan kreteria di atas maka diperoleh 80 sampel laporan keuangan bank yang go publik dari 16 bank yang memenuhi syarat untuk pengambilan sampel selama periode 2004-2008. 80 sampel tersebut terdiri atas 56 bank sehat (70\%) dan 24 bank tidak sehat (30\%).

\section{Uji Kelayakan Model (Goodness of Fit)}

Pengujian ini diperlukan untuk memastikan tidak ada kelemahan atas kesimpulan dari model yang diperoleh. Langkah pertama adalah menilai overall fit model terhadap data. Hipotesis untuk menilai model fit adalah :

Ho : Model yang dihipotesakan fit dengan data

HA : Model yang dihipotesakan tidak fit dengan data

Berdasarkan hasil pengujian tersebut diperoleh nilai Chi-Square 0.421 dengan signifikansi sebesar 1,000. Dimana nilai signifikansinya lebih besar daripada nilai alpha $(0,05)$ berarti menerima Ho atau model yang dihipotesakan fit dengan data. Model yang dihipotesakan layak diterima karena cocok dengan data observasinya sehingga dapat dipergunakan untuk penelitian.

Langkah kedua menilai keseluruahn model dengan membandingkan angka awal -2 Log Likelihood yang terdapat pada awal (Blok Number $=0$ ) dengan angka akhir pada -2 Log Likelihood (Blok Number = 1) Dari hasil uji SPSS pada tabel tersebut dapat dilihat bahwa terjadi penurunan nilai -2logL yang pada awal sebesar 97.776 menjadi sebesar 19.165. Penurunan tersebut menandakan bahwa model regresi yang dipergunakan dalam penelitiasn ini adalah baik.

Langkah ketiga dalam keseluruahan model fit adalah dengan menggunakan Koefisien Determinasi $\left(\mathrm{R}^{2}\right)$, dimana $R^{2}$ bertujuan untuk mengukur seberapa jauh kemampuan model dalam menerangkan variasi variabel independen. Koefisien Determinasi $\left(\mathrm{R}^{2}\right)$ digunakan untuk mengetahui ukuran ketepatan model yang dipakai dalam penelitian ini. Hal ini dinyatakan dengan berapa besar persentase variabel dependen (Y) yang dapat dijelaskan oleh variabel independenya (X).

Dalam penelitian ini Koefisien Determinasi $\left(R^{2}\right)$ diwakili dengan Cox dan Snell's $R$ Square yang dapat diinterpretasikan sama seperti nilai Koefisien Determinasi $\left(R^{2}\right)$ pada regresi berganda. Sehingga berdasarkan tabel diatas diketahui nilai Cox dan Snell's R Square sebesar 0,625 sedangkan nilai yang terdapat pada Nagelkerke $R$ Square sebesar 0,887 dimana hal tersebut menunjukan bahwa variabilitas dari variabel dependen dapat dijelaskan dengan variabilitas variabel independen sebesar $88.7 \%$. Hal ini juga berarti bahwa $88,7 \%$ rasio-rasio keuangan CAMELS (CAR, APB, KAP, NPM, ROA, ROE, NIM, BOPO, LDR, IRR) serta variabel kualitatif mampu untuk menjelaskan perbedaan pada variabel dependennya (tingkat kesehatan bank). Sedangkan sisanya sebesar $11,3 \%$ kondisi dari bank, baik dalam kondisi sehat maupun tidak sehat dipengaruhi oleh faktor luar dari 
penelitian CAMELS (Capital, Asset Quality, Management, Earning, Liquidity, Sensitivity to Market Risk) ini seperti kebijakan pemerintah, keprcayaan dari masyarakat, kondisi makro ekonomi, maupun inflasi.

\section{Uji Hipotesis}

Setelah mendapatkan model regresi logistik yang fit yang tidak memerlukan modifikasi model, maka pengujian hipotesis dapat dilakukan. Hasil pengujian hipotesis dilakukan dengan menggunakan uji secara parsial. Pengujian kemaknaan prediktor secara parsial dilakukan dengan menggunakan uji Wald dan dengan pendekatan chi square dapat dilihat pada tabel 1

Estimasi maksimum likelihood parameter dari model dapat dilihat pada tampilan output variabel in the equation logistic regression. Pada step 2 terdapat 2 variabel independen yang signifikan yaitu Return on Asset (ROA) dan Interest Risk Ratio (IRR). Variabel bebas Return on Asset (ROA) dan Interest Risk Ratio (IRR) signifikan pada prob 0,05. Dari persamaan logistik regression di atas dapat dilihat bahwa log of odds Bank mempunyai kesehatan secara positif dipengaruhi oleh Return on Asset (ROA) dan interest Risk Ratio (IRR).

Variabel capital yang diukur dengan rasio CAR. Capital Adequacy Ratio (CAR) merupakan rasio kecukupan modal yang digunakan untuk menutup resiko kemungkinan rugi yang ditimbulkan dari kegiatan usaha. Dari hasil penelitian diperoleh nilai signifikan 0,079 > 0,05 dengan demikian Ho ditolak dan H1 . Maka dapat disimpulkan bahwa Capital Adequacy Ratio (CAR) tidak berpengaruh terhadap prediksi kesehatan Bank. Penelitian ini mendukung dari penelitian yang dilakukan oleh Titik Aryati \& hekinus Manao yang menyatakan bahwa Capital Adequacy Ratio (CAR) tidak mempengaruhi keberhasilan atau kegagalan bank. Namun penelitian ini bertolak belakang dengan penelitian yang dilakukan oleh Luciana Spica Almilia \& Winny Herdiningtyas yang menyatakan bahwa Capital Adequacy Ratio (CAR) mempunyai pengaruh yang signifikan terhadap kondisi bermasalah bank.

Hal ini terjadi karena adanya peraturan Bank Indonesia tentang Capital Adequacy Ratio (CAR) yang menyatakan bahwa Capital Adequacy Ratio (CAR) Bank Umum minimal sebesar 8\%. Kondisi ini mengakibatkan bahwa bank selain menjaga agar peraturan tentang Capital Adequacy Ratio (CAR) tersebut selalu dapat dipenuhi. Namun bank cenderung menjaga agar Capital Adequacy Ratio (CAR) tidak lebih dari 8\% karena ini berarti idle fund atau bahkan pemborosan, karena sebenarnya modal utama bank adalah kepercayaan, sedangkan Capital Adequacy Ratio (CAR) 8\% hanya dimaksudkan Bank Indonesia untuk menyesuaikan kondisi dengan perbankan internasional.

Variabel asset quality yang diukur dengan rasio Aktiva Produksi Bermasalah (APB) dan Kualitas Aktiva Poduktif (KAP) diperoleh nilai signifikan sebesar 0,677 dan 0,858 dimana jumlah tersebut melebihi alpha 0,05, dengan demikian Ho ditolak dan H1 diterima. Maka dapat disimpulkan bahwa rasio Aktiva Produksi Bermasalah (APB) dan Kualitas Aktiva Poduktif (KAP) tidak berpengaruh terhadap prediksi kesehatan Bank. Penelitian ini mendukung dari penelitian yang dilakukan oleh Luciana Spica Almilia \& Winny Herdiningtyas yang menyebutkan bahwa rasio Aktiva Produktif Bermasalah (APB) mempunyai pengaruh yang tidak signifikan terhadap kondisi bermasalah bank.

Hal ini dapat dilihat dengan data yang ada menunjukan bahwa Aktiva Produksi Bermasalah (APB) dan 
Kualitas Aktiva Poduktif (KAP) memiliki mean rata-rata keseluruhan bank sebesar 3,3701 dan 3,7865 dengan nilai max sebesar 58,30 dan 63,08, sehingga dapat dikatakan secara rata-rata keseluruhan bank dari segi kualitas asset yang dimiliki oleh bank kurang baik atau dapat dikatakan buruk.

Dalam hal ini variabel management yang diukur dengan Net Profit Margin (NPM) diperoleh nilai signifikan 0,214 > 0,05 dengan demikian Ho ditolak dan H1 diterima. Hal ini dapat disimpulkan bahwa Net Profit Margin (NPM) tidak berpengaruh secara signifkan terhadap prediksi kesehatan Bank. Penelitian ini mendukung dari penelitian yang dilakukan oleh Titik Aryati \& Hekinus Manao (2002) yang menyebutkan bahwa Net Profit Margin (NPM) tidak mempengaruhi keberhasilan atau kegagalan bank. Hal ini mengidentifikasikan bahwa Net Profit Margin (NPM) rata-rata keseluruhan bank memiliki mean sebesar $0.4727 \%$ hal ini berarti kemampuan ratarata keseluruhan bank dalam mengahsilkan net income sebesar 0,4727\% dari operating income. Sedangkan rata-rata keseluruhan mean aktiva produktif yang bermasalah sebesar 3,3701\%. Jadi hipotesis penelitian yang menyatakan Net Profit Margin (NPM) berpengaruh dalam memprediksi tingkat kesehatan bank adalah ditolak atau tidak dapat diterima.

Dalam hal ini variabel earning yang diukur dengan Return on Asset (ROA), Return on Equity (ROE), Net Interest Margin (NIM) dan Beban Operasional terhadap Pendapatan Operasional (BOPO). Dari hasil penelitian regresi logistik hanya Return on Asset (ROA) yang diperoleh nilai Wald sebesar 5,558 dengan signifikansi 0,018 $<$ 0,05dengan demikian Ho diterima dan H1 ditolak. Maka dapat disimpulkan bahwa Return on Asset (ROA) berpengaruh signifikan terhadap prediksi kesehatan bank. Pengaruh ini menunjukan setiap kenaikan Return on Asset (ROA) akan diikuti semakin tingginya tingkat kesehatan bank. Sebaliknya setiap penurunan Return on Asset (ROA) akan diikuti dengan semakin turunnya tingkat kesehatan bank. Hasil penelitian ini mendukung penelitian yang dilakukan oleh Titik Aryati \& Hekinus Manao yang menyatakan bahwa rasio Return on Asset (ROA) memiliki pengaruh signifikan terhadap prediksi bank yang bermasalah.

Sedangkan Return on Equity (ROE), Net Interest Margin (NIM), Beban Operasional terhadap Pendapatan Operasional (BOPO) diperoleh nilai signifikan sebesar 0,609; 0,417 dan 0,088 dimana jumlah tersebut melebihi alpha 0,05, dengan demikian Ho ditolak dan $\mathrm{H} 1$ diterima. Maka dapat disimpulkan bahwa Return on Equity (ROE), Net Interest Margin (NIM), Beban Operasional terhadap Pendapatan Operasional (BOPO) tidak mempunyai pengaruh signifikan terhadap prediksi kesehatan Bank. Hasil penelitian ini sesuai dengan penelitian yang dilakukan oleh Penni Mulyaningrum yang menyatakan bahwa Return on Equity (ROE), Net Interest Margin (NIM), Beban Operasional terhadap Pendapatan Operasional (BOPO) tidak mempunyai pengaruh yang signifikan dalam memprediksi kesehatan perbankan tahun 2006. Hal ini mengidentifikasikan bahwa dengan Beban Operasional terhadap Pendapatan Operasional (BOPO), rata-rata keseluruhan bank dalam menjalankan usahanya tidak dengan efisien hal ini terlihat dari mean Beban Operasional terhadap Pendapatan Operasional BOPO lebih besar dari $96 \%$ dan dengan nilai max sebesar $1226.28 \%$.

Dalam hal ini variabel likuidity yang diukur dengan Loan Deposit Ratio (LDR) diperoleh nilai signifikan 0,713>0,05 dengan demikian Ho ditolak dan H1 diterima. Maka dapat disimpulkan bahwa Loan Deposit Ratio (LDR) tidak berpengaruh signifikan terhadap prediksi kesehatan Bank. Hasil penelitian ini bertolak belakang 
dengan penelitian yang dilakukan oleh Penni Mulyaningrum yang menyatakan bahwa Loan Deposit Ratio (LDR) mempunyai pengaruh yang signifikan terhadap prediksi kebangkrutan bank tahun 2006. Namun hasil penelitian ini mendukung hasil penelitian dara Luciana Spica Almilia dan Winny Herdiningtyas yang menyatakan bahwa Loan Deposit Ratio (LDR) tidak mempunyai pengaruh yang signifikan dalam memprediksi bank bermasalah.

Hal ini disebabkan karena adanya penambahan modal dari pemilik yang berupa fresh money untuk mengantisipasi skala usaha yang berupa expansi kredit atau pinjaman yang diberikan. Tetapi pada kenyataannya sampai saat ini bank belum dapat melempar pinjaman sesuai dengan yang diharapkan atau masih belum optimal, dimana dana pihak ketiga yang berupa simpanan dana masyarakat oleh bank dibelikan Sertifikat Bank Indonesia daripada untuk memberikan kerdit kepada masyarakat. Sehingga membuat kepercayaan masyarakat akan bank menjadi turun.

Dalam hal ini variabel sensitivity to market risk yang diukur dengan Interest Risk Ratio (IRR) diperoleh nilai Wald sebesar 9,049 dengan signifikansi sebesar 0,003 < 0,05 dengan demikian Ho diterima dan $\mathrm{H} 1$ ditolak. Maka dapat disimpulkan bahwa Interest Risk Ratio (IRR) berpengaruh signifikan terhadap prediksi kesehatan bank. Pengaruh ini menunjukan setiap kenaikan Interest Risk Ratio (IRR) akan diikuti dengan semakin tingginya tingkat kesehatan bank. Sebaliknya setiap penurunan Interest Risk Ratio (IRR) akan diikuti dengan semakin turunnya tingkat kesehatan bank. Dimana bank dapat dikatakan sehat bila kemampuan bank dalam mendapatkan bunga lebih besar daripada biaya yang dikeluarkan untuk membayar beban bunga yang ditanggung oleh bank.

\section{SIMPULAN}

Berdasarkan hasil analisis statistik model regresi logistik terhadap 80 sampel dari 16 bank mulai tahun 2004 - 2008 mampu memprediksi kesehatan bank dengan propabilitas sebesar 88,7 \%. Hasil pengujian data dan hipotesa dengan menggunakan model regresi logistik dengan tingkat signifikan sebesar $5 \%$ menunjukan bahwa Return on Asset (ROA) dan Interst RiskRatio (IRR) mempunyai pengaruh yang signifikan dalam memprediksi tingkat kesehatan bank. Hal ini dapat dilihat dengan tingkat signifikan yang dimiliki oleh rasio Return on Asset (ROA) dan Interst Risk Ratio (IRR) sebesar 0,018 dan 0,003 dimana jumlah tersebut kurang dari nilai alpha 5\%.

\section{DAFTAR REFERENSI}

Bank Indonesia. 2004. PBI No 6/10/PBI/2004 Tentang Sistem Penilaian Tingkat Kesehatan Bank Umum. Jakarta. Indonesia.

Bank Indonesia. 2004. Surat Edaran No 6/23/DPNP Perihal Sistem Penilaian Tingkat Kesehatan Bank Umum. Jakarta. Indonesia.

C. Trihendradi. 2006. "Langkah Mudah Menguasai Statistik Menggunakan SPSS 15 Deskriptif, Parametrik, Non Parametrik". Yogyakarta : Andi 
Enik Sulastri. 2009. "Analisis Rasio Keuangan untuk Menilai Kinerja Keuangan Perbankan Syariah Periode 20032007". Skripsi Universitas Muhammadiyah Surakarta. Surakarta.

Evi Astutik. 2009. "Analisis Kesehatan Bank Berdasarkan Model CAMELS pada Perusahaan Perbankan Go Publik yang Terdaftar di Bursa Efek Indonesia Periode 2005-2007". Skripsi Universitas Muhammadiyah Surakarta. Surakarta.

Imam Ghozali. 2007. “Aplikasi Analisis Multivariate Dengan Program SPSS". Semarang: Badan Penerbit Universitas Diponegoro

Jonathan Sarwono. 2006. "Panduan Cepat dan Mudah SPSS 14". Yogyakarta : Andi.

Luciana Spica Amilia dan Winny Herdiningtyas. 2005. "Analisis Rasio Camel Terhadap Prediksi Kondisi Bermasalah Pada Lembaga Perbankan Periode 2000-2002". Jurnal Akuntansi \& Keuangan. Fakultas Ekonomi Universitas Kristen Petra. Vol.7, No.2.

Mega Indah Budiyanto. 1998. "Rasio Keuangan yang Dapat Meprediksi Kebangkrutan Bank.Skripsi Universitas Kristen Petra.

Nur Indriantoro \& Bambang Supomo. 2002. "Metodologi Penelitian Bisnis". Yogyakarta: BPFE-Yogyakarta.

Penni Mulyaningrum. 2008. "Analisis Rasio Keuangan sebagai Indikator Prediksi Kebangkrutan Bank di Indonsia". Tesis Universitas Diponegoro. Semarang.

Sri Haryati. 2001. "Analisis Kebangkrutan Bank". Jurnal Ekonomi dan Bisnis Indonesia. Jurnal Ekonomi dan Bisnis. Vol. 16, No. 4, 2001. 336-345.

Sugiono, 2002, Metodologi Penelitian Bisnis, Alfa Beta, Bandung.

Tarmizi Achmad \& Willyanto Kartiko Kusuno. 2003. "Analisis Rasio-Rasio Keuangan sebagaio Indikator dalam Memprediksi Potensi Kebangkrutan Perbankan di Indonesia". Media Ekonomi \& Bisnis. Vo.XV. No.1. Juni 2003.

Titik Aryati \& Hekinus Manao. 2002. "Rasio Keuangan sebagai Prediktor Bank Bermasalah di Indonesia". Jurnal Riset Akuntansi Indonesia. Vol. 5. No. 2. Mei 2002. Hal. 137-147. 
Lampiran

Tabel 1 : Koefisien Fungsi Logistik Regresi Bank di Indonesia Tahun 2004-2008

Variables in the Equation

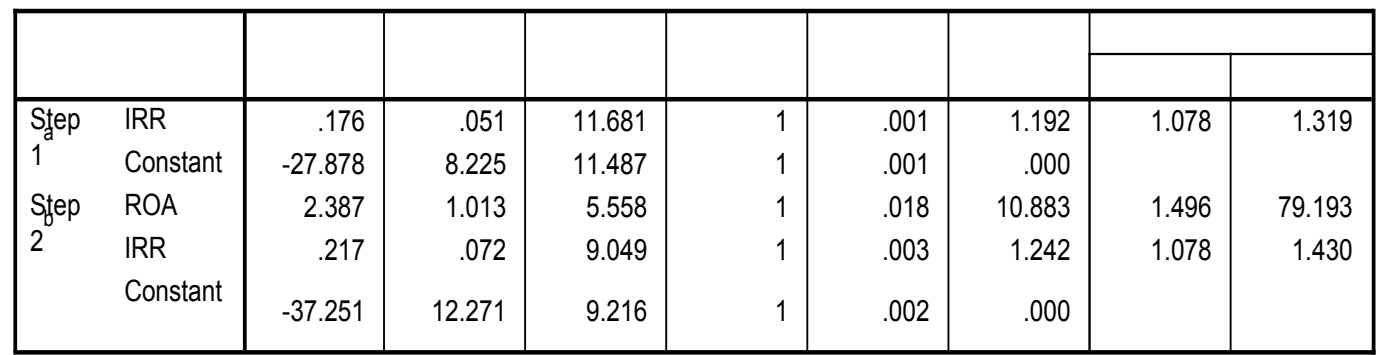

Sumber : Data yang diolah, 2010

Tabel 2 : Uji Model Fit

\begin{tabular}{|c|c|c|}
\hline \multicolumn{2}{|c|}{ Uji Model Fit } & Hasil \\
\hline Hosmer and Loweshow Test & Chi Square & 0,421 \\
\hline & Sig & 1.000 \\
\hline -2 Log Likehood & -2 LL Blok Number 0 & 97.738 \\
\hline Cox \& R nell R Square & -2 LL Blok Number 1 & 19.165 \\
\hline Nagelkerke R Square & Cox & 0.625 \\
\hline & Nagel & 0.887 \\
\hline
\end{tabular}

Sumber : data yang diolah 2010 